\title{
顕微鏡画像を用いた根端成長の数理モデル解析
}

\author{
岩元明敏 ${ }^{1}$, 杉山宗隆 ${ }^{2}$ \\ 1 東京学芸大学教育学部自然科学系広域科学講座生命科学分野 $=184-8501$ 東京都小金井市貫井北町 4-1-1 \\ 2 東京大学大学院理学系研究科附属植物園 T112-0001 東京都文京区白山 3-7-2
}

\begin{abstract}
要旨 : 植物の根端成長は遺伝要因や環境要因によって大きな影響を受けるが，そうした影響は細胞増殖と体積増大の変化を反 映している. この両者について正確な空間プロファイルを得るには, 細胞動力学的解析が有効である. これは器官の成長を「細胞 の流れ」としてとらえる解析法であり，根端成長に適用すると根の任意の位置でじの程度細胞体積が増大し，細胞が増殖している かが定量的に示される．具体的には，まず定常的な成長下にある根から，ビデオマイクロスコープを用いて一定時間間隔で根端 画像を取得し，これらの画像を解析することで体積増大 (伸長成長) 速度の空間プロファイルを決定する。 また，細胞増殖につい ては, 微分干渉顕微鏡を用いて撮影した根端の皮層細胞列の画像を解析し, 個々の細胞の長さを決定し, 体積増大速度のデー 夕と合わせることで増殖率の空間プロファイルを算出する。 こうして得られたデータは，それ自体，根の成長に関して重要な基本情 報を提供するが，私達はさらに，独自の数理モデルによるデータ解析を行って，隠れた成長特性の究明を試みている. このモデ ルは, 器官が成長するための活動量がその器官が持つ細胞数に比例すること, 活動量が細胞増殖, 体積増大, 器官維持の総 和となることなどを仮定したもので, 器官成長の各側面 (細胞増殖, 体積増大, 器官維持)のコストを見積もることができる. 本総説 では，細胞動力学的解析の具体的な方法論とそのデータを用いた数理モデル解析を紹介する.
\end{abstract}

\section{Mathematical-model-assisted analysis of root growth using microscope images}

\author{
Akitoshi Iwamoto $^{1}$, Munetaka Sugiyama ${ }^{2}$ \\ ${ }^{1}$ Department of Biology, Tokyo Gakugei University, 4-1-1 Nukui-kita-machi, Koganei-shi, Tokyo 184-8501, Japan \\ ${ }^{2}$ Botanical Gardens, Graduate School of Science, The University of Tokyo, 3-7-1 Hakusan, Bunkyo-ku, Tokyo 112-0001, Japan \\ Author for correspondence: A. Iwamoto, akitoshi@u-gakugei.ac.jp
}

\begin{abstract}
Summary: Root apical growth is altered by genetic and/or environmental influences, which is attributable to changes in cell proliferation and volume growth. For investigating spatial profiles of these two parameters, "cell flux"-based kinematic analysis offers a powerful tool. Kinematic analysis of the root growth answers the question of where and at what rates cells proliferate and increase their volumes. The first step of kinematic analysis is to determine the spatial profile of root elongation rates from time-lapse images of a steadily growing root that are captured by a videomicroscope at a certain interval. Next, cell length is measured along the root axis on a differential interference contrast microscopic image, and the collected cell length data are used together with the spatial profile of elongation rates to determine the spatial profile of cell proliferation rates. We further analyze these profiles by an original mathematical model, which assumes several relationships between cell number, cell proliferation rate, and volume growth rate, to estimate costs of various aspects of the root growth. Here we describe the methodology of kinematic analysis of the root growth and application of our mathematical model.
\end{abstract}

Key words: microscopic image, root growth, kinematic analysis, mathematical model

\section{はじめに}

植物の成長は根本的には茥頂と根端という2つの軸の先端 成長に還元することができ, 植物の器官における形態形成も, 基本的にはこの先端成長の調節によって支えられていると言え る (岩元 2008)。植物の先端成長の一方である根端の成長は, 最先端部の分裂域における活発な細胞増殖と，それに続く伸 長域における細胞体積の増大 (＝体積増大) とを特徴とする (Beemster et al. 2003). 遺伝・環境要因による根の成長の違 いは，この $2 つ の$ 側面の変化によるが，それらは独立ではなく 互いに密接に関連している，根端成長を構成するこれらの各 側面の空間プロファイルを明らかにし，両者の複合的な関係 を解明することは，先端成長の制御のあり方，さらに遺伝・環 境要因による成長の変化の本質を理解する上できわめて重要 である.

成長中の器官から体積増大と細胞増殖の詳細なデータを
取得するをためには, 細胞動力学的手法 (“cell flux”-based kinematic analysis) による解析が有効である. 細胞動力学的手 法とは, 生理学的な前提を特に置かず, 器官の成長を物理 的な「細胞の流れ」として捉えて解析することで，器官の体積 増大と細胞増殖を定量化する手法である (Gandar 1983). 根端 成長に対して細胞動力学的手法を適用することで，成長の各 側面に関する空間プロファイルを得ることができる. この手法は 特に一次元的な成長をする根端成長の解析に有効であり, 実 際にこの手法を用いて，シロイヌナズナ根端における皮層細 胞と表皮細胞の成長の違い(Beemster and Baskin 1998), オー キシンが与える影響 (Beemster and Baskin 2000, Swarup et al. 2005, Rahman et al. 2007), 塩ストレスが及ぼす影響（West et al. 2004), 倍数体を含めたエコタイプ間の成長の違い (Iwamoto et al. 2006），エチレンが与える影響 (Swarup et al. 2007) など の定量的解析が行われている. 
この細胞動力学的手法で得られた根端成長における細胞増 殖と体積増大の空間プロファイルを比較すると, 両者の間にい くつかの関係が見て取れる．私達はこうした関係を定式化した 数理モデルを用いて, 細胞動力学的データの解析を行ってい る (Iwamoto et al. 2006). このように細胞動力学的手法と数理 モデルを組み合わせることにより, 成長の各側面の複合的な 関係性を踏まえた，より深い成長解析が可能となる。

本総説では，まず細胞動力学的手法を用いてシロイヌナズ ナ根端の顕微鏡画像から成長の各パラメータに関するデータ を抽出し, 空間プロファイルを得るための具体的な方法につい て説明する. さらに, 私達が独自に考案した数理モデルを紹 介し，このモデルで空間プロファイルのデータを解析すること で得られる結果についても概説する.

\section{根端成長の細胞動力学的解析}

根端成長の細胞動力学的解析の第一段階は, 根端部の顕

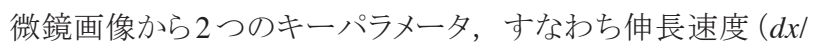
$d t)$ と細胞長 $(d x / d N)$ の空間プロファイルを抽出することである $(x$ はある地点の静止中心からの距離, $N$ は静止中心からその地 点までの間にある細胞の数). 最初に伸長速度の方から説明 していく.

根端の様々な位置での伸長速度, 寸なわち伸長速度の空 間プロファイルを明らかにするためには, ある時間間隔 $\Delta t て ゙$ 撮 影した顕微鏡 (通常, 高精度のビデオマイクロスコープを用い る) 画像において同一点を特定する必要がある. 画像間で各 同一点を比較し，それらが $\Delta t$ の間に移動した距離を計測する ことにより，根端の様々な場所での伸長速度を求められる(図 1)。 静止中心からの距離 $x_{i}$ の位置における伸長速度であれば, 下 記の式により求めることができる.

$$
\frac{d x}{d t}\left(x_{i}\right) \approx \frac{\Delta x}{\Delta t}\left(x_{i}\right)=\frac{x_{i}(t+\Delta t)-x_{i}(t)}{\Delta t}
$$

この伸長速度の測定では, 従来は測定者が 2 枚の画像を 見比べて一つ一つ同一点を判断した上で, 位置を読み取っ て手作業で計算ソフトに入力する，というような方法が採られ

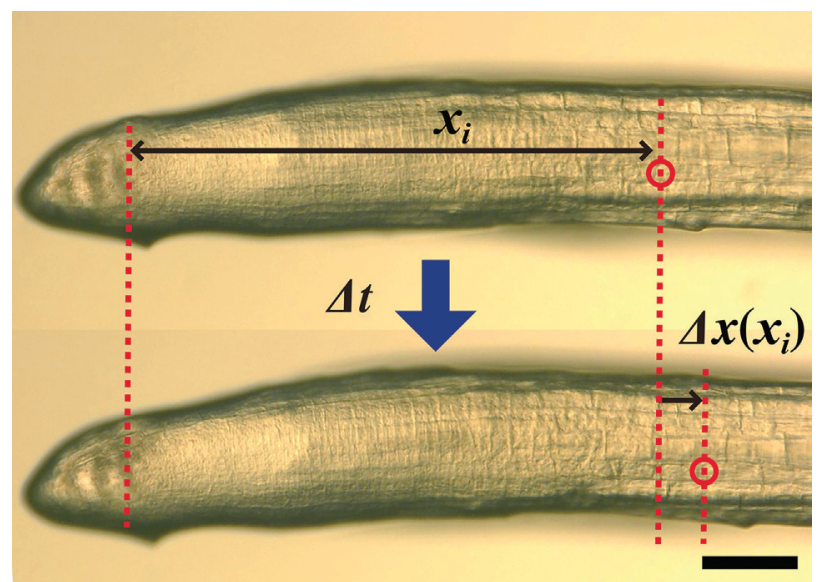

図 1 根端における伸長速度の測定. 一定時間 $(\Delta t)$ 間隔で 2 枚の 画像を撮影し, 1 枚目の画像の任意の位置 $\left(x_{i}\right)$ における点と, それ に対応する 2 枚目の画像の点, つまり同一点（赤丸）を判定する. こ の同一点の移動距離 $\left(\Delta x\left(x_{i}\right)\right)$ から, 任意の点での伸長速度を求める. Scale bar $=100 \mu \mathrm{m}$.
てきた (Beemster and Baskin 1998, Iwamoto et al. 2006). し かし, この方法は多大な労力を要し, また同一点が判定しに くい部分については測定者の恣意的判断に影響されやすい という問題があった. こうした問題を解決するため, 伸長速 度の測定を自動化するコンピュータプログラムも開発されてい る. そのなかで比較的使用実績があるのはRoot FlowRT (van der Weele et al. 2003)で, これを用いて行われた研究も少な からず発表されている (Gruner et al. 2010, Rahman et al. 2007, Swarup et al. 2005, Swarup et al. 2007). しかし, このプログ ラムは, 同一点の判定に断続的に撮影した多数の精密な画 像を必要とするなど, なおいくつかの問題を残していた. そこ で私達は一定時間間隔を置いて撮影した 2 枚の顕微鏡画像 のみから同一点を判定し, 伸長速度を自動的に算出するプロ グラム “GrowthTracer”を開発した (Iwamoto et al. 2013)。この GrowthTracerは根端の成長解析に広く適用可能で, 既にシ ロイヌナズナの変異体の解析などに用いている (ex., Toyoda et al. submitted).

伸長速度を測定した根は, 次にもう1つのキーパラメータで ある細胞長の測定に供する. 細胞長を測定するには, 細胞の 輪郭を識別できるような顕微鏡画像が必要となる。これには, 通常は固定・透明化後に微分干涉顕微鏡で撮影した画像 (図 2）が用いられるが，蛍光色素で染色してから共焦点レーザー 顕微鏡で撮影した画像を用いている例もある (Swarup et al. 2007)。根では組織ごとに細胞が列をなしており, 細胞長の測

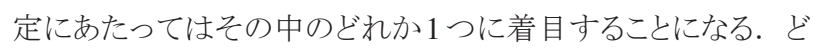
の細胞列を選択するかは研究の目的にもよるが, シロイスナズ ナの根端成長に関して言えば，ほとんどの場合，皮層細胞列 が解析対象として選択されている (Beemster and Baskin 2000, Beemster et al. 2002, Swarup et al. 2005, Iwamoto et al. 2006, Swarup et al. 2007).

以上の測定で得られる伸長速度と細胞長は, 静止中心を基 準とした距離ベースのデータである. しかし，根端は実際には 放射方向にも成長しており, その程度は環境条件や変異体に よって異なる. 放射方向の成長を含めた根端成長を細胞動力 学的に扱うには, 距離ベースのデータから体積ベースのデー タへの変換を行う. シロイヌナズナの根端の皮層を解析する場

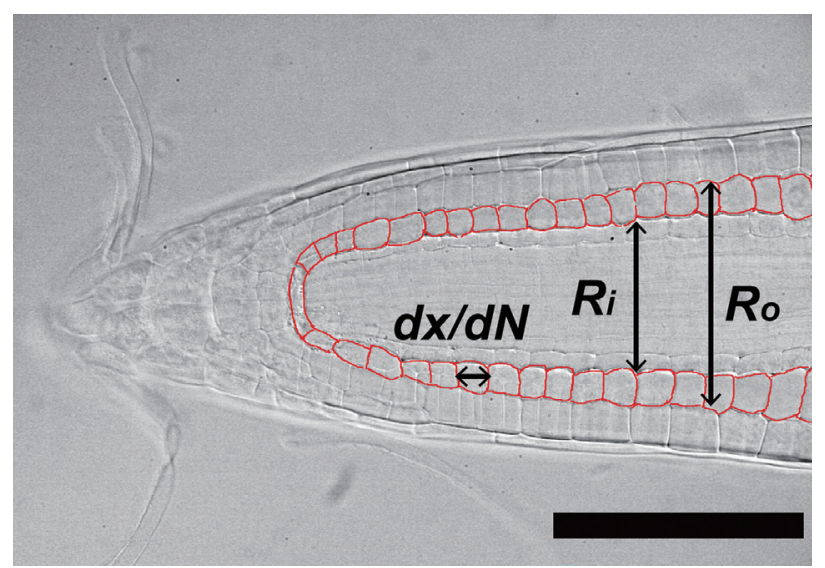

図 2 根端における皮層細胞列の細胞長の測定. 微分干涉顕微鏡を 用いて撮影した画像から皮層細胞列（輪郭が赤でトレースされている） における細胞長 $(d x / d N)$ を測定する. また，パラメータを体積ベース に変換するために, 皮層の内径 $\left(R_{i}\right)$ と外径 $\left(R_{o}\right)$ も同じ根端で測定 する. Scale bar $=100 \mu \mathrm{m}$. 
合は，皮層を8つの細胞列からなる回転体とみなして，体積ベー スに変換することができる (Iwamoto et al. 2006). 静止中心か ら距離 $x$ の位置での皮層細胞列 1 列の断面積 $S$ は, 以下の式 から求められる.

$S(x)=\frac{\pi}{8}\left[\left\{R_{o}(x)\right\}^{2}-\left\{R_{i}(x)\right\}^{2}\right]$

ここで $R_{o}, R_{i}$ は皮層細胞列の外径, 内径を表しており，細 胞長の測定と同時に測定できるパラメータである (図 2).ささら に, この断面積 $S$ を 0 (静止中心) から距離 $x$ まで積分することで, 静止中心から距離 $x$ の地点までの皮層細胞列の累積体積 $V$ が 得られる。

$V(x)=\int_{0}^{x} S(x) d x$

以上のような方法により, 伸長速度 $(d x / d t)$ は体積増大速 度 $(d V / d t)$ に, 細胞長 $(d x / d N)$ は細胞体積 $(d V / d N)$ に変換さ

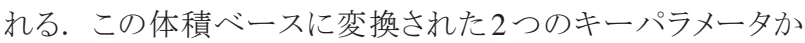
ら, 細胞増殖率 $(d N / d t)$, 細胞数 $(N)$, 相対成長率 (Relative Elementary Growth Rate $=$ REGR), 局所的細胞増殖率 $($ Local Cell Production Rate = LCPR) といったパラメータを求めること ができる. 細胞増殖率に関しては，まず細胞体積の逆数をと ることで細胞密度 $(d N / d V)$ を得てから, この細胞密度と体積増 大速度を用いて，以下の式により算出する.

$\frac{d N}{d t}=\frac{d N}{d V} \times \frac{d V}{d t}$

ただし，式 (4) が成り立つのは，厳密には根が定常的な成 長状態にある場合, すなわち細胞密度の空間プロファイルの 時間変化がない場合である. 細胞密度の変化があるときには, それを取り入れて細胞増殖率を計算する必要がある (Beemster and Baskin 1998) が，通常の生育条件では根端皮層細胞列の 細胞密度の変化は微小であり細胞増殖率の算出結果に大きな 影響を与えないことを確認している(岩元, 未発表データ). また, 静止中心からの任意の位置における皮層細胞の数 $(N)$ は, 以 下の通り積分を行うことで求められる.

$N=\int_{0}^{V} \frac{d N}{d V} d V$
さらに，体積増大速度をVで微分することでREGRを，細 胞増殖率を $V$ で微分することでLCPRをそれぞれ求めることが できる.

$\operatorname{REGR}=\frac{d\left(\frac{d V}{d t}\right)}{d V}$

$\mathrm{LCPR}=\frac{d\left(\frac{d N}{d t}\right)}{d V}$

ここで算出したREGRの空間プロファイルは，「根端の任意 の位置でどのくらい体積が大きくなるか」を表しており, REGR が正の值をとる範囲が根端における体積増大域となる。 また, LCPRの空間プロファイルは,「根端の任意の位置でどのくら い細胞が生産されるか」を表しており，LCPRが正の值をとる範 囲が細胞増殖域を示す．解析結果の例として, Columbia株 の 2 倍体と4倍体のREGR およびLCPR の空間プロファイルを 図3に示す. また, 以上の細胞動力学的解析の流れをまとめて, 図4Aに示す.

\section{細胞動力学的データの数理モデル解析}

植物の器官成長に関して, 私達は体積増大と細胞増殖の 関係を定式化した数理モデルを考案し，これを細胞動力学的 手法と組み合わせて, 根端成長の解析に用いている (Iwamoto et al. 2006). この数理モデルは以下の3つの仮定に基づいて おり, 式 (8)のような簡潔な微分方程式によって表される.

仮定 1： 器官の成長活動の総量は，そこに含まれる細胞 数によって規定される.

仮定 2：器官の成長活動は, 「細胞増殖」,「体積成長」, 「器官維持」といら3つの側面からなる.

仮定 3： 器官の維持には, その体積に応じた成長活動量 の割り当てを必要とする.

$\alpha N=C_{1} \frac{d N}{d t}+C_{2} \frac{d V}{d t}+C_{3} V$

ここでは $N$ は細胞数, $V$ は器官の体積, $\alpha$ は細胞当たりの 成長活動量係数, $C_{1}, C_{2}, C_{3}$ はそれぞれ体積増大のコスト係

\section{O REGR O LCPR}

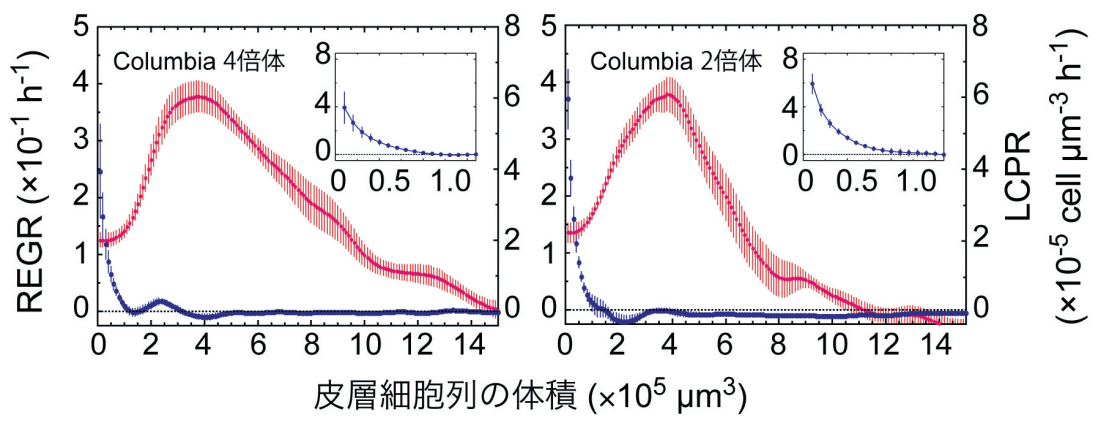

図3 細胞動力学的手法による根端成長の解析結果の例 (Iwamoto et al. 2006 より一部改編).シロイヌナズナColumbia株の4倍体と2 倍体について, REGR とLCPR の空間プロファイルをグラフとして示した. 差し込み図は LCPR の先端付近での拡大図を示す. このグラフから 4 倍体では 2 倍体に 比べて体積増大域は拡大するが，細胞増殖域の大きさに違いがないことが分かる. 
数, 細胞増殖のコスト係数, そして器官維持のコスト係数を表す. また, $\alpha, C_{1}, C_{2}, C_{3}$ は解析対象とする組織に固有の定数とした.

このモデルが実際の根端成長の空間プロファイルをどう反映 しているかを, 細胞増殖と体積増大との関係性を例に見てみよう. 式 (8)を皮層細胞列の累積体積 $(V)$ で微分すると,

$\alpha \frac{d N}{d V}=C_{1} \frac{d\left(\frac{d N}{d t}\right)}{d V}+C_{2} \frac{d\left(\frac{d V}{d t}\right)}{d V}+C_{3}$
となる. 式 (9) の左辺は細胞密度, 右辺はLCPR とREGR の和であることから，LCPRとREGRに一種のトレードオフの関 係があることが示される. 細胞動力学的解析で得られたLCPR とREGRのグラフ (図3) でも, LCPR の減少に伴って REGRが 上昇しており, トレードオフの存在を窥わせる結果となっている,

この数理モデルによる解析では, 成長の各側面の相対コス 卜 (効率) が推定できる. 図4に示したように, 数理モデルの式 （8）全体を成長活動量 $\alpha$ で除した式に, 細胞動力学的解析に よって求めた根端成長の各パラメータである細胞数 $(N)$, 細胞

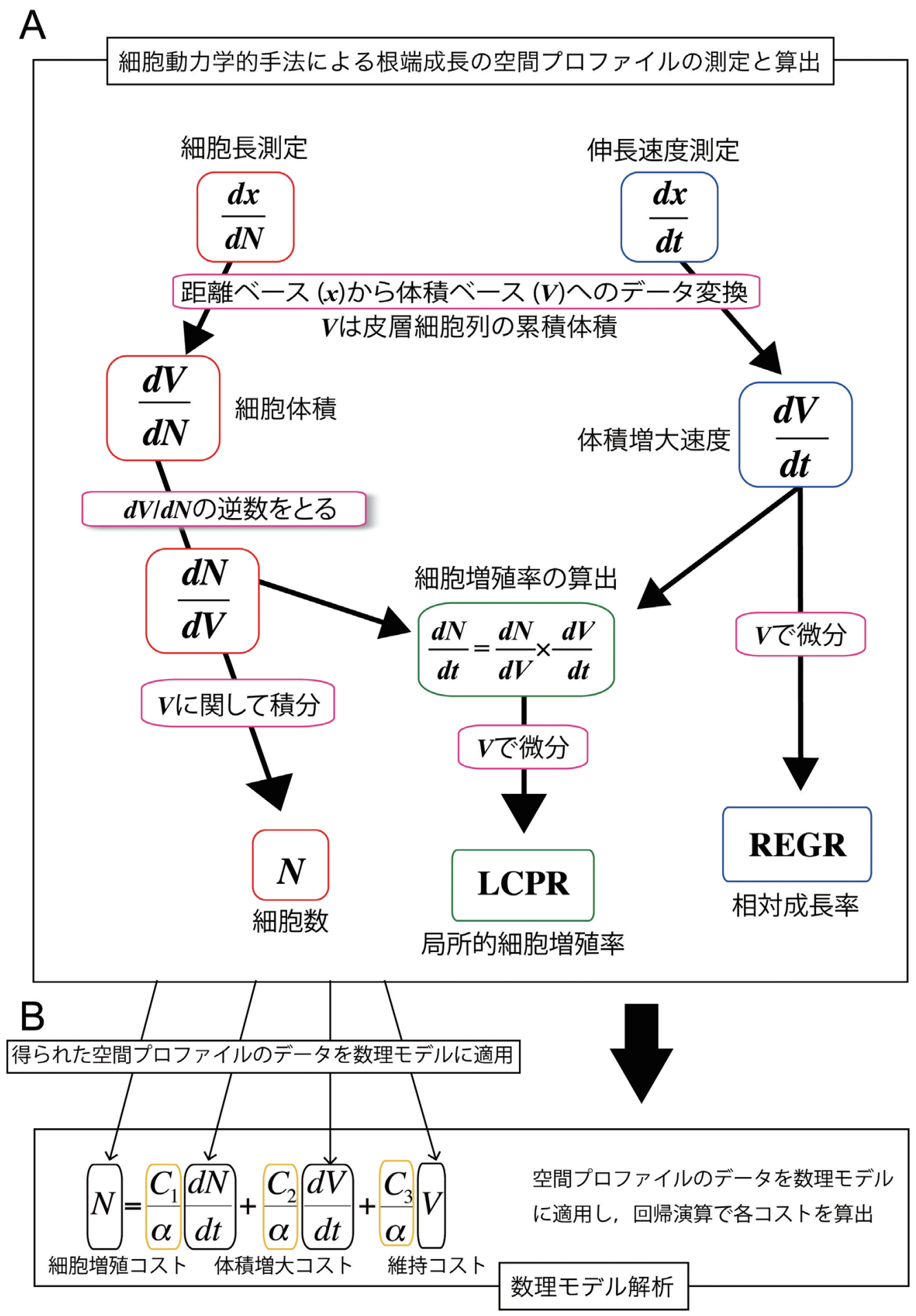

図 4 細胞動力学的手法による根端成長の解析（A）と数理モデル解析（B）の概略図 


\begin{tabular}{ccccc}
\hline & $\begin{array}{c}C_{1} / \alpha \\
(\mathrm{h})\end{array}$ & $\begin{array}{c}C_{2} / \alpha \\
\left(10^{-5} \text { cell h } \mu \mathrm{m}^{-3}\right)\end{array}$ & $\begin{array}{c}C_{3} / \alpha \\
\left(10^{-6}{\left.\operatorname{cell~} \mu \mathrm{m}^{-3}\right)}\right.\end{array}$ & $R^{2}$ \\
\hline Columbia 4 倍体 & 19.1 & 5.95 & 6.06 & 0.966 \\
Columbia 2 倍体 & 15.4 & 9.71 & 9.85 & 0.942 \\
\hline
\end{tabular}

$C_{1} / \alpha$ は細胞増殖のコスト值, $C_{2} / \alpha$ は体積増大のコスト值 $C_{3} / \alpha$ は器官維持のコス

卜值. $R^{2}$ は $R^{2}=1-\left\{\sum\left(N-N_{e s t}\right)^{2} / \sum\left(N-N_{\text {mean }}\right)^{2}\right\}$ として求められ, 大きいほど数理 モデルが実測の空間プロファイルと一致していることを示す（最大值は 1 ). 2 倍 体，4倍体ともに 10 本分の根端の空間プロファイルのデータを平均し, 数理モデ ル解析に用いた。

増殖率 $(d N / d t)$ ，体積増大速度 $(d V / d t)$ および皮層細胞列の 累積体積 $(V)$ の空間プロファイルを適用すると，重回帰分析 によって細胞増殖コスト $C_{l} / \alpha$, 体積増大コスト $C_{2} / \alpha$, 器官維持 コスト $C_{3} / \alpha$ を算出することができる. これらのコスト值はそれぞれ， 細胞増殖率，体積成長速度，体積を 1 単位増加させるのに 必要な細胞数を示しており，值が大きいほど成長の各側面の 効率は低く，小さいほど効率は高いことを示す。

表 1 は，シロイヌナズナColumbia系統の 2 倍体と4倍体の 細胞動力学データに, 数理モデル解析を適用した結果である (Iwamoto et al. 2006). 4倍体のコストを2倍体と比較すると, $C_{I} / \alpha$ の違いは小さい一方で, $C_{2} / \alpha, C_{3} / \alpha$ はともに $65 \%$ 程度に 減少している。この結果は，ゲノム量が倍加すると，体積増大 と器官維持の効率は高くなるが, 細胞増殖の効率はあまり変 わらないことを示唆している.

このように私達が考案した数理モデルを用いることにより，体 積増大と細胞増殖の複合的な関係に基づいて各側面の効率 を見積もり，根端成長を新たな視点から特徵づけることができる. これは単に細胞動力学的解析を行うだけでは明らかにできな いことであり, 数理モデル解析の有効性を示している. しかし, モデルによる予測と実測データとの間には無視できない構成 的な偏差も見られ，現在のモデルが (大枠としては妥当である としても) 何らかの問題を含んでいることが示唆される. その一 つと予想されるのが，核内倍加の問題である. シロイスナズナ の根端では通常核内倍加が起きており（Breuer et al. 2007）, 皮層細胞列についても根端の位置によって細胞 1つあたりの ゲノム量が異なる，そのため，細胞 1 つたたりの成長活動量も 異なっていると考えられ，それに応じて数理モデルを修正しな くてはならない。実際，核内倍加の影響を考慮して数理モデ ルを修正したところ，数理モデルによる予測值と実測データと の適合度が改善した (岩元，未発表)，現在，この改変したモ デルの検証を進めているところであり，今後は改変モデルを適 用することで，より精度の高い成長解析が可能になると期待し ている.

\section{謝辞}

本総説は,日本植物学会第76回大会シンポジウム「Beyond Imaging～進化する超顕微技術のパイオニア・シンポジウム 〜」の講演の内容を元にまとめた. また，本総説と関連する研 究の一部は科学研究費補助金, 新学術領域研究 (no. 231195 to AI) および特定領域研究 (no. 19060001 to MS) による助成 を受けて行われた。 elongation underlying the developmental acceleration of root growth in Arabidopsis thaliana. Plant Physiol 116: 1515-1526.

Beemster, G. T. S., and Baskin, T. I. (2000) STUNTED PLANT mediates effects of cytokinin, but not of auxin, on cell division and expansion in the root of Arabidopsis. Plant Physiol 124: 1718-1727.

Beemster, G. T. S., De Vusser, K., De Tavernier, E., De Bock, K., and Inze, D. (2002) Variation in growth rate between Arabidopsis ecotypes is correlated with cell division and A-type cyclin-dependent kinase activity. Plant Physiol 129: 854-864.

Beemster, G. T. S., Fiorani, F., and Inze, D. (2003) Cell cycle: the key to plant growth control? Trends Plant Sci 8: 154-158.

Breuer, C., Stacey, N. J., West, C. E., Zhao, Y., Chory, J., Tsukaya, H., Azumi, Y., Maxwell, A., Roberts, K., and Sugimoto-Shirasu, K. (2007) BIN4, a novel component of the plant DNA topoisomerase VI complex, is required for endoreduplication in Arabidopsis. Plant Cell 19: 3655-3668.

Gandar, P. W. (1983) Growth in root apices I. The kinematic description of growth. Bot Gaz 144: 1-10.

Gruner, A., Hoverter, N., Smith, T., and Knight, C. A. (2010) Genome size is a strong predictor of root meristem growth rate. J Bot 2010: $1-4$.

岩元明敏（2008）先端成長の多様性と基本システムへのアプローチ. Plant Morphol 19: 65-72.

Iwamoto, A., Kondo, E., Fujihashi, H., and Sugiyama, M. (2013) Kinematic study of root elongation in Arabidopsis thaliana with a novel image-analysis program. J Plant Res 126: 187-192.

Iwamoto, A., Satoh, D., Furutani, M., Maruyama, S., Ohba, H., and Sugiyama, M. (2006) Insight into the basis of root growth in Arabidopsis thaliana provided by a simple mathematical model. $J$ Plant Res 119: 85-93.

Rahman, A., Bannigan, A., Sulaman, W., Pechter, P., Blancaflor, E. B., and Baskin, T. I. (2007) Auxin, actin and growth of the Arabidopsis thaliana primary root. Plant J 50: 514-528.

Swarup, R., Kramer, E. M., Perry, P., Knox, K., Leyser, H. M., Haseloff, J., Beemster, G. T., Bhalerao, R., and Bennett, M. J. (2005) Root gravitropism requires lateral root cap and epidermal cells for transport and response to a mobile auxin signal. Nature Cell Biol 7: 1057-1065.

Swarup, R., Perry, P., Hagenbeek, D., Van Der Straeten, D., Beemster, G. T., Sandberg, G., Bhalerao, R., Ljung, K., and Bennett, M. J. (2007) Ethylene upregulates auxin biosynthesis in Arabidopsis seedlings to enhance inhibition of root cell elongation. Plant Cell 19: 2186-2196.

van der Weele, C. M., Jiang, H. S., Palaniappan, K. K., Ivanov, V. B., Palaniappan, K., and Baskin, T. I. (2003) A new algorithm for computational image analysis of deformable motion at high spatial and temporal resolution applied to root growth. Roughly uniform elongation in the meristem and also, after an abrupt acceleration, in the elongation zone. Plant Physiol 132: 1138-1148.

West, G., Inze, D., and Beemster, G. T. S. (2004) Cell cycle modulation in the response of the primary root of Arabidopsis to salt stress. Plant Physiol 135: 1050-1058.

\section{引用文献}

Beemster, G. T. S., and Baskin, T. I. (1998) Analysis of cell division and 